\title{
Structure and yield of all-sized and even-sized conifer-dominated stands on fertile sites
}

\author{
E Lähde, O Laiho, Y Norokorpi, T Saksa
}

The Finnish Forest Research Institute, Box 18, FIN-01301 Vantaa, Finland

(Received 4 June 1993; accepted 22 September 1993)

\begin{abstract}
Summary - The material studied consisted of 807 sample plots located in SW Finland. The data were inventoried (in 1951-1953) using a systematic temporary circular plot line survey. Each plot represented a particular stand. An all-sized stand structure (ie a stem distribution resembling an inverted letter $\mathrm{J}$ ) amounted to $62 \%$ of sample plots whereas $25 \%$ were even-sized (resembling a normal distribution) and $13 \%$ were irregularly uneven-sized. The number of stems per ha in allsized stands was nearly twice that of even-sized stands. The mean annual increment increased linearly with an increase in volume. Consequently, there was no difference in increment between all-sized and even-sized stands because the volume of the growing stock in the latter group was greater than in the former. The mean annual increment in stands with equal average volumes was, however, greater in all-sized mixed stands than in even-sized conifer stands. The relative growth in all-sized mixed stands was approximately $25 \%$ higher than in corresponding even-sized stands.
\end{abstract}

stem distribution / stand structure / yield / all-sized stand / even-sized stand / fertile site

Résumé - Structure et rendement de peuplements irréguliers et réguliers à majorité de conifères sur terrains fertiles. Le matériel d'étude est constitué de 807 placettes d'échantillonnage réparties dans le sud-ouest de la Finlande (fig 1). Les données étaient inventoriées (1951-1953) au moyen de placettes circulaires temporaires systématiques alignées. Chaque placette représentait un peuplement particulier. Des placettes d'échantillonnage (62\%) avaient une structure de peuplement irrégulière (c'est-à-dire avec une distribution des diamètres des tiges ressemblant à la lettre $J$ inversée), $25 \%$ une structure régulière (ressemblant à une distribution normale des tiges) et $13 \%$ une structure irrégulière aux diamètres inégaux. Le nombre de tiges par hectare dans les structures irrégulières atteignait presque le double de celui des structures régulières (fig 2). L'accroissement annuel moyen augmentait de façon linéaire avec l'augmentation en volume (fig 3). Par conséquent, il n'y avait pas de différence d'accroissement entre les peuplements irréguliers et les peuplements réguliers car le volume du matériel sur pied croissant du dernier groupe était plus grand que celui du premier groupe (tableau 1). L'accroissement annuel moyen de peuplements à volume moyen égal était toutefois plus grand dans des peuplements mélangés irréguliers que dans des peuplements de conifères réguliers (tableau II). La croissance relative des peuplements mélangés irréguliers était environ $25 \%$ plus élevée que celle des peuplements correspondants réguliers.

distribution des tiges / structure de peuplement / rendement / peuplement irrégulier / peuplement régulier / terrain fertile 


\section{INTRODUCTION}

Even-sized (even-aged) forestry and allsized (uneven-aged) forestry are the 2 main principles applied in the tending of forests. All-sizedness (all-agedness) is the term applied to stands whose stem distribution more or less resembles an inverted letter $\mathrm{J}, i e$ the number of trees in the diameter classes diminishes as the diameter increases (de Liocourt, 1898; Baker, 1934; Meyer, 1952; Alexander and Edminster, 1978; Curtis, 1978; Gibbs, 1978; Daniel et al, 1979). Oliver and Larson (1990) refer to stands whose stem distribution resembles an inverted letter $\mathrm{J}$ by the name multicohort stands. In this study such stands are referred to as all-sized stands. Even-sizedness (even-agedness) is loosely defined as referring to stands whose stem distribution roughly resembles a normal distribution (Curtis, 1978; Gibbs, 1978; Gingrich, 1978; Daniel et al, 1979). This approach is applied in this study as well. A more precise criterion involves the application of a certain range of diameter classes (Smith, 1962; Daniel et al, 1979). This range may be, for instance, 12 or $20 \mathrm{~cm}$ (Lähde et al, 1991, 1992).

Diameter at breast height is the generally used means of depicting age differences. However, tree age and tree size do not always correlate very well. In fact, tree growth has been observed to be more dependent on size than age (Cajander, 1934; Sarvas, 1944; Vuokila, 1970; Indermühle, 1978). On being released from the dominance of larger trees, the trees forming the understorey generally attain the same size as those that have always been free to grow (Cajander, 1934; Näslund, 1944; Hawley, 1946; Hatcher, 1967; Schütz, 1969; Indermühle, 1978; Nilsen and Haveraaen, 1983; Klensmeden, 1984). When diameter is used as the criterion for structure it is more appropriate to use the terms allsized and even-sized instead of all- or uneven-aged and even-aged. The termino- logy used in this study complies with this view.

Both practicing foresters as well as researchers have participated in the ageold debate on which of the 2 principles is better (Hassenkamp, 1955; Børset, 1963; Carbonnier, 1978; Mikola, 1984; Viitala, 1986). The prevailing opinion has varied from country to country - even in cycles of a few decades (Mustian, 1978).

In Fennoscandia, the raising of evensized forest stands became the standard practice around the middle of this century. During the following decades the opposition to silviculture aimed at all-sized stand structure was extremely strong in the Nordic countries, especially in Sweden and Finland. Thereafter, however, forest use has become diversified. The role of forests in recreation, protection of the environment and the landscape as well as in other aspects of multiple-use has received increasing attention. Growing interest has been directed to the ways in which forests are treated (Smith, 1972, 1975; Gould, 1975; Vrablec, 1977; Doolittle, 1978; Gibbs, 1978; Lundqvist, 1984). For instance, in the United States the general trend has led to the development of silvicultural regimes aimed at raising structurally all-sized forests (Gingrich, 1967; Leak et al, 1969; Gibbs, 1978; Hann and Bare, 1979). In the case of the Nordic countries this stage has only just begun (Lähde et al, 1985; Hagner, 1992a, 1992b; Haveraaen, 1992; Lähde, 1992; Larsen, 1992).

Although the dispute over the main policy to be followed in the raising of forests has been an on-going issue for decades, there are only few long-term silvicultural experiments comparing the differences between the opposed policies. Separate studies are, however, available on the 2 options. The number of studies conducted on the raising of even-sized stands clearly exceeds that of all-sized silviculture despite the fact that natural development results in highly diverse 
forest structure (Ilvessalo, 1920a, 1920b; Sirén, 1955; Kammerlander, 1978; Larsen, 1980; Heinselman, 1981; Solomon et al, 1986; Norokorpi, 1992). This diversity is often accompanied by all-sizedness (Ussva, 1932; Pobedinski, 1988; Lähde et al, 1991, 1992).

With the exception of some studies (eg Bøhmer, 1957; Mitscherlich, 1963; Kern, 1966; Hasse and Ek, 1981; Pretzsch, 1985; Solomon et al, 1986; Haight and Gets, 1987; Lundqvist, 1989), the comparison of the differences between these 2 silvicultural policies has remained at the level of rough estimations only. Several simulation models have also been developed for different growing stocks in the case of all-sized silviculture (Eyre and Zillgitt, 1953; Trimble, 1961, 1970; Hart, 1964; Marquis et al, 1969; Mayer, 1969; Frank and Björkom, 1973; Adams and Ek, 1974; Hladik, 1975; Leak and Graber, 1976). Inventories of timber resources represent a hitherto little appreciated means of obtaining comparative data on forest yield and structure.

The material chosen for this study consists of part of the data collected in the course of the 3rd national forest inventory carried out in Finland. In the study all-sized and even-sized stands of conifers and of mixed species are compared in terms of occurrence, structure and yield on fertile sites. In accordance with the concept generally accepted in the Nordic countries, the hypotheses applied in the study are: (1) that mixed broad-leaved-coniferous stands grow better than conifer stands; and (2) that evensized stands grow better than all-sized stands.

\section{MATERIALS AND METHODS}

The 3rd national forest inventory (1951-1953) in Finland was conducted as a systematic temporary circular plot line survey (Ilvessalo, 1951). Until then the forests of Finland had generally been treated with various forms of light selection felling and thinning from above. Dimension felling has also been widely used (Ilvessalo, 1956).

Southwestern Finland (fig 1) was chosen for this study because of its uniform climatic conditions. The material was collected from fertile mineral soil sites (Myrtillus site type or more fertile, see Cajander, 1949).

The mean dominant height (100 thickest trees/ha) was also measured on most of the plots. Because the age of dominant trees was not exactly determined, the site (height) index of the plot stands could not be estimated. However, dominant height measured may give a good base for comparisons of site quality. According to Indermühle (1978) biological age is not characteristic in uneven-aged forests because growing in suppression causes an overestimation of age. In general, the site index is difficult to estimate in uneven-aged forests (Andreassen, 1992).

The stands were in thinning, preparatory or regeneration cutting stages, with a volume of at least $40 \mathrm{~m}^{3} / \mathrm{ha}$. The growing stock was generally dominated by Norway spruce (Picea abies $L$ Karst), with admixtures of Scots pine (Pinus sy/vestris $\mathrm{L}$ ) and broad leaved species (Betula pendula Roth $20 \%$, B pubescens Ehrh $50 \%$ and others, mainly Alnus incana, 30\%). The silvicultural state had to be good or satisfactory or the stands had to have been untreated for many years (llvessalo, 1951).

Each sample plot represented a particular stand, ie it was located entirely within one stand (livessalo, 1951). Thus, the structure on any plot could not be admixture of different stands. The size of the plots was 0.1 ha $\left(1000 \mathrm{~m}^{2}\right)$ and all trees with dbh (diameter at breast height) over $10 \mathrm{~cm}$ were measured. Small trees (dbh 2-10 $\mathrm{cm}$ ) were tallied from within a concentric circle with an area of $0.01 \mathrm{ha}\left(100 \mathrm{~m}^{2}\right)$.

In this study the trees were divided according to $\mathrm{dbh}$ into $4 \mathrm{~cm}$ diameter classes as follows: $1=2-6 ; 2=6-10 ; 3=10-14 ; 4=14-18$; $5=18-22 ; 6=22-26 ; 7=26-30 ; 8=30-34$; and $9=>34 \mathrm{~cm}$. Broad leaved trees of vegetative origin were not tallied as they were not assumed to be capable of developing into actual trees. The sample plots were individually classified according to the structure as follows (applying the classifications used by Smith (1962) and Daniel et al (1979)):

$\mathrm{J}$ : All-sized. Stem distribution resembling an inverted letter $\mathrm{J}$; trees present in at least the 4 smallest 


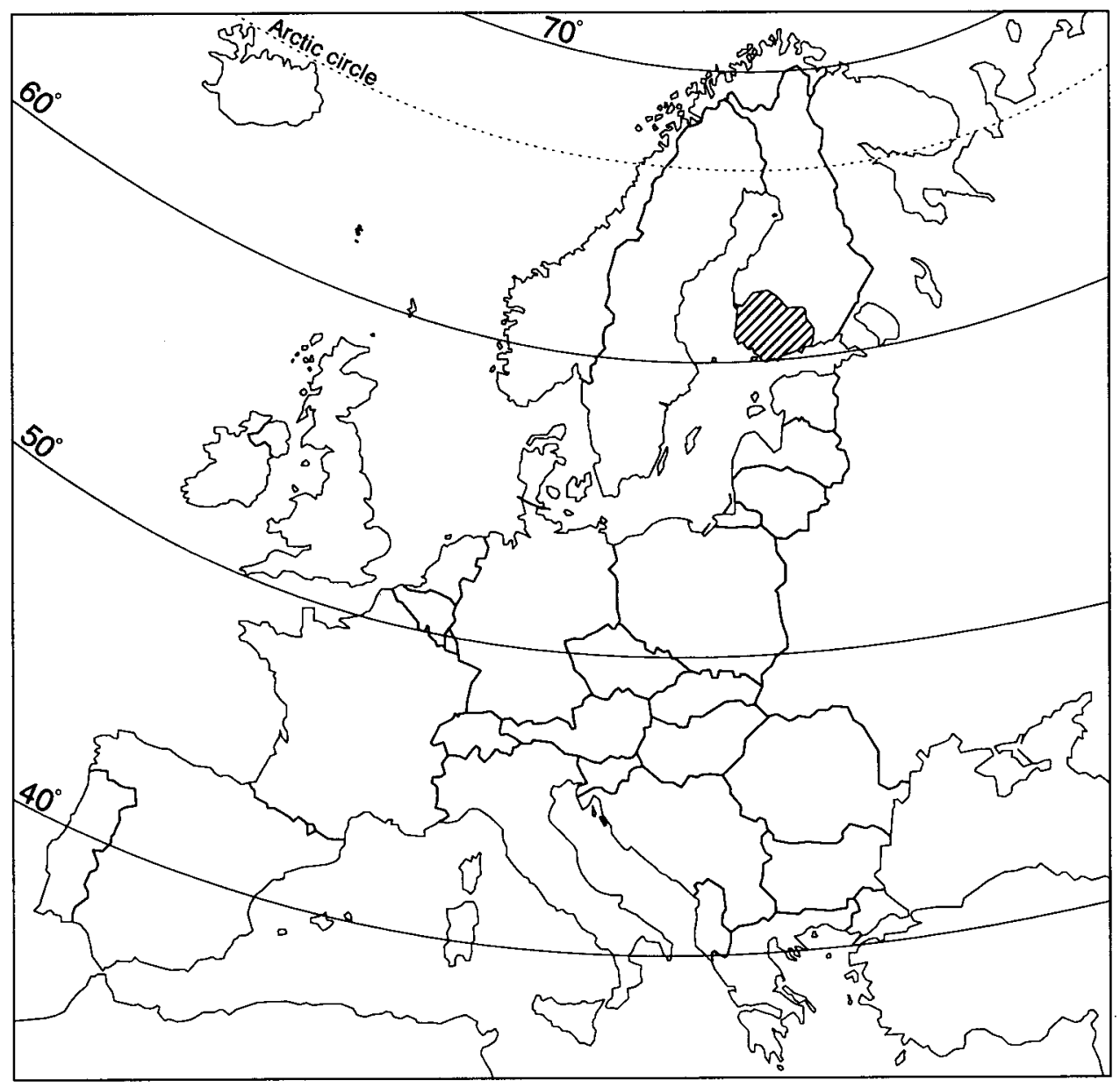

Fig 1. Study area in southwestern Finland.

diameter classes, with the mode in the first or second class (502 sample plots);

E: Even-sized. Stem distribution resembling a normal distribution; mode in neither of the 2 smallest diameter classes nor at either end of the distribution (197 sample plots);

$O$ : Others (irregularly uneven-sized) (108 sample plots, only some main results are given).

Classifications of another kind have also been used in describing the stand structure. Leemans (1991) and Szwagrzyk (1992), for instance, used the age, height, dbh, and exact tree location as characters.

A total of 807 sample plots were studied (table 1). The structural groups were divided into 2 sub-groups on the basis of the stem number of broad-leaved species. The division is generally made according to volume or basal area. In stands that were all-sized in structure the number of small trees is, however, important for stand development. The species groups were as follows: 
Table I. Parameters $(x \pm \mathrm{se})$ of the stands studied. Results of 2-way analysis of variance and Tukey's test.

\begin{tabular}{|c|c|c|c|c|c|}
\hline $\begin{array}{l}\text { Stand } \\
\text { structure }\end{array}$ & $\begin{array}{c}\text { Tree } \\
\text { species group }\end{array}$ & Sample plots & $\begin{array}{l}\text { Relative growth } \\
\text { (\%) }\end{array}$ & $\begin{array}{l}\text { Volume } \\
\left(m^{3} / h a\right)\end{array}$ & $\begin{array}{c}\text { Mean increment } \\
\left(m^{3} / \mathrm{ha} / \mathrm{a}\right)\end{array}$ \\
\hline \multirow[t]{2}{*}{ All-sized } & Conifer & 160 & $3.6\left(0.1^{a}\right)$ & $155\left(5^{a}\right)$ & $5.2\left(0.1^{a}\right)$ \\
\hline & Mixed & 342 & $4.3\left(1.1^{b}\right)$ & $137\left(3^{b}\right)$ & $5.5\left(0.1^{a}\right)$ \\
\hline \multirow{2}{*}{ Even-sized } & Conifer & 119 & $3.1\left(0.1^{c}\right)$ & $187\left(6^{c}\right)$ & $5.4\left(0.2^{a}\right)$ \\
\hline & Mixed & 78 & $3.4\left(0.1^{\mathrm{ac}}\right)$ & $177\left(7^{\circ}\right)$ & $5.7\left(0.2^{a}\right)$ \\
\hline \multicolumn{2}{|c|}{$F$-value, structure } & & $37.98^{* * *}$ & $54.28 * * *$ & 1.87 \\
\hline \multicolumn{2}{|c|}{$F$-value, tree species } & & $15.94^{* * *}$ & $8.31 * *$ & 4.07 \\
\hline \multicolumn{2}{|c|}{ interaction } & & 4.29 & 0.62 & 0.15 \\
\hline
\end{tabular}

Values with different small letters differ statistically $(p<0.05)$ from each other.

A: Conifer stands. No more than 120 broad-leaves trees per ha (average $=78$ ).

B. Mixed (broad leaved-coniferous) stands. More than 120 broad leaved trees per ha (average $=$ 698 ; basal area $30 \%$ ).

Comparison of the yield between different stand groups is presented as a mean annual increment (excluding bark) for the total material and for the same average volume class, and as a relative growth (\%). The effect of stand structure and tree species composition on different stand parameters was analysed with 2-way analysis of variance. The differences between different group means were tested with Tukey's test. The dependence between mean annual increment and volume in stands with different structure and tree species composition was analysed with regression analysis.

\section{RESULTS}

\section{Structure, species composition and stem number}

The stem number in mixed stands was higher than in conifer stands (fig 2). The proportion of broad-leaved species in the mixed stands averaged $34-41 \%$. The broadleaved species particularly increased the proportion of small trees. Broad-leaved trees with diameters over $30 \mathrm{~cm}$ were observed only on some sample plots. The stem number in all-sized stands was 2329 stems/ha; this was more than twice as much as the 1079 stems recorded in even-sized stands and almost twice as much as in irregularly uneven-sized stands where the figure was 1173.

In all-sized stands, on average, the stem distribution of both Norway spruce and broad-leaved species resembled an inverted letter $\mathrm{J}$ just as the overall stem distribution did. Correspondingly, the stem distribution of the various tree species in even-sized stands resembled a normal distribution in the same way as the overall stem distribution did (fig 2). The proportion of Scots pine was greater in these $(15 \%)$ than it was in all-sized stands ( $8 \%$ ). The difference in the overall number of stems between the structural groups was a consequence of the number of spruce and broad-leaved species.

\section{Yield}

The relative growth (mean of 5 previous years, \%) in mixed stands was higher than 

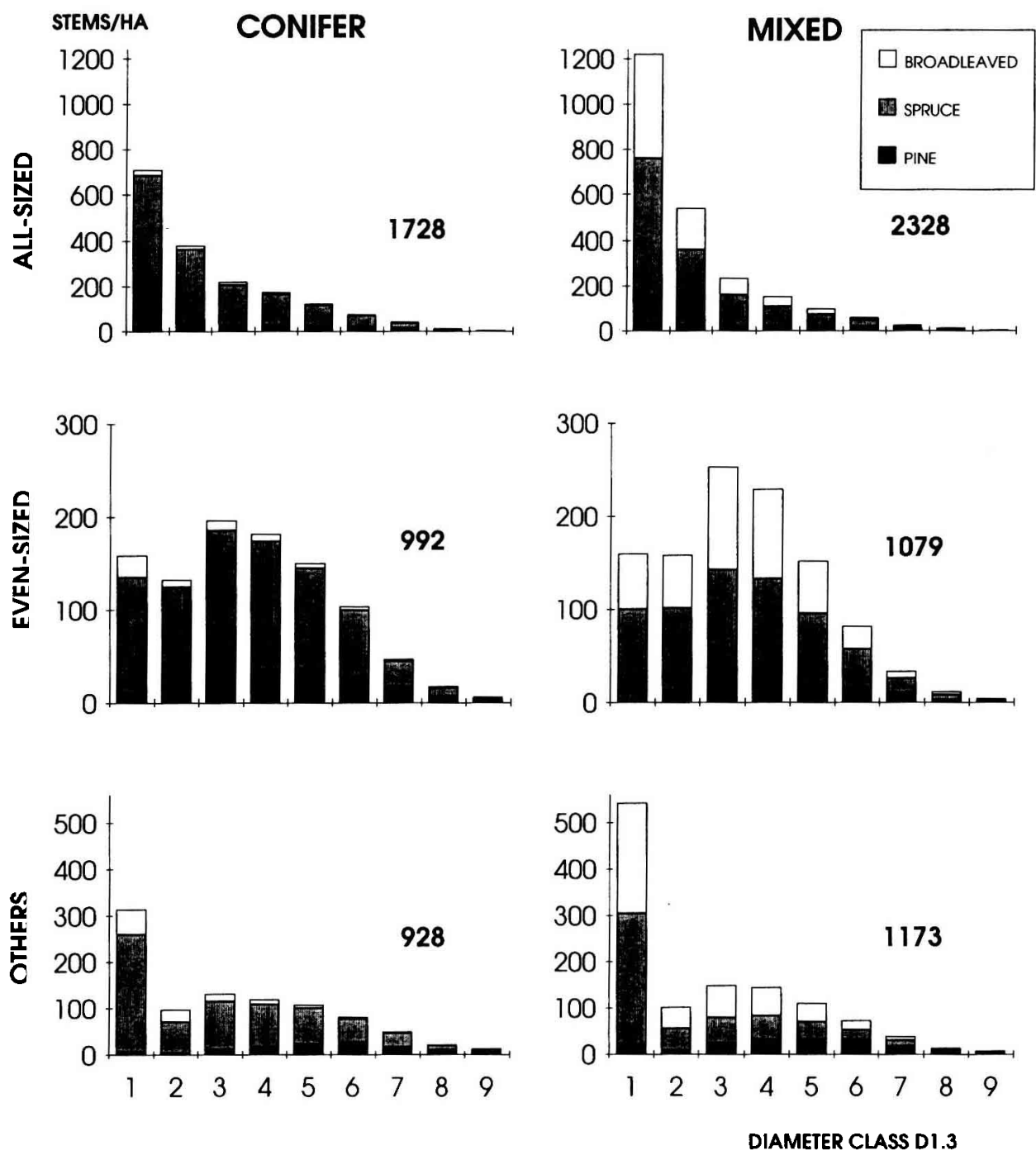

Fig 2. Average stem distribution in stands of different structure and tree species composition. Observe the scales showing stem number in the subfigures. Legends: dbh - classes: $1=2-6 ; 2=$ $6-10 ; \ldots, 9=>34 \mathrm{~cm}$. Total stem numbers/ha are given in the subfigures.

in conifer stands (table I). However, only the largest difference (19\%), in all-sized stands, was statistically significant $(p<0.01)$. The relative growth in both all-sized conifer and mixed stands was significantly $(p<$ $0.01)$ higher than in the corresponding evensized stands.
The volume of the growing stock in mixed stands was less than that in conifer stands. This was also the case when comparing all-sized stands with even-sized stands. The differences in mean annual increment averages between these groups were not statistically significant (table I). A 


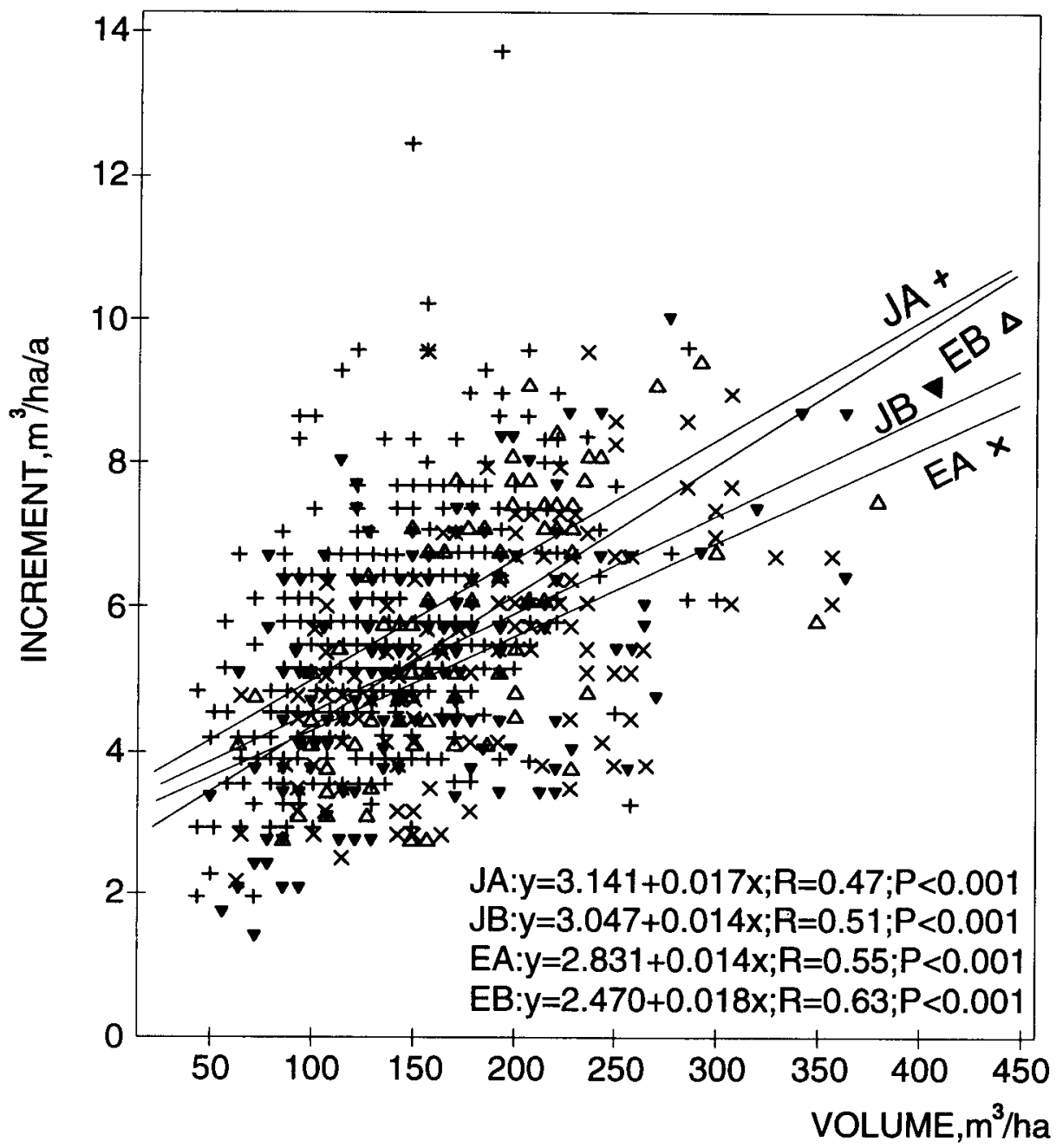

Fig 3. Dependence between mean annual increment and volume in all-sized $(\mathrm{J})$ and even-sized $(\mathrm{E})$ stands. $\mathrm{A}=$ conifer and $\mathrm{B}=$ mixed stands.

positive linear dependence applied between mean annual increment and volume (fig 3). When the volume in all-sized mixed stands, for instance, rose from $100 \mathrm{~m}^{3} / \mathrm{ha}$ to $300 \mathrm{~m}^{3} / \mathrm{ha}$, the mean annual increment rose by $\approx 3 \mathrm{~m}^{3} / \mathrm{ha}$.

The dominant height $(\bar{x}, \mathrm{se}, \mathrm{m})$ in allsized and even-sized stands is presented in the following setting:

$\begin{array}{lll}\text { All-sized } & \text { Conifer } & 19.1 \pm 0.2 \\ & \text { Mixed } & 18.3 \pm 0.2 \\ \text { Even-sized } & \text { Conifer } & 20.0 \pm 0.3 \\ & \text { Mixed } & 20.1 \pm 0.3\end{array}$

The dominant height in all-sized stands differed significantly $(p<0.05)$ from that in even-sized stands. The difference between 
conifer and mixed stands was significant only in the all-sized group.

The mean annual increment in all-sized mixed stands with equal average volume (152 $\pm 15 \mathrm{~m}^{3} / \mathrm{ha}$ ) was a quarter higher (1.2 $\mathrm{m}^{3} / \mathrm{ha}$, under bark) than that of even-sized conifer stands (table II). The difference in growth for these structure groups was statistically significant $(p<0.05)$. The over-bark (average bark 16\%; Ilvessalo, 1956) mean annual increment was $7.0 \mathrm{~m}^{3} / \mathrm{ha}$ in this allsized mixed stand group.

The dominant height $(\bar{x}$, se, $m)$ of these groups was as follows:

$\begin{array}{lll}\text { All-sized } & \text { Pure conifer } & 18.6 \pm 0.4 \\ & \text { Mixed } & 19.2 \pm 0.3 \\ \text { Even-sized } & \begin{array}{l}\text { Pure conifer } \\ \text { Mixed }\end{array} & 19.3 \pm 0.5 \\ & \text { Mixed } & 20.8 \pm 0.3\end{array}$

Table II. Comparison of mean annual increment $\left(\bar{x}\right.$, se, $\left.\mathrm{m}^{3} / \mathrm{ha}\right)$ in stands of different structure and tree species composition and with equal average volumes (mean 15215 $\mathrm{m}^{3} \mathrm{ha}$ ). Results of 2-way analyses of variance and Tukey's test (log transformation).

\begin{tabular}{|c|c|c|c|}
\hline $\begin{array}{l}\text { Stand } \\
\text { structure }\end{array}$ & $\begin{array}{l}\quad \text { Tree } \\
\text { species } \\
\text { groups }\end{array}$ & $\begin{array}{l}\text { Sample } \\
\text { plots }\end{array}$ & $\begin{array}{c}\text { Mean annua } \\
\text { increment } \\
\text { (excluding } \\
\text { bark) }\end{array}$ \\
\hline All-sized & $\begin{array}{l}\text { Conifer } \\
\text { Mixed }\end{array}$ & $\begin{array}{l}25 \\
63\end{array}$ & $\begin{array}{l}5.3\left(0.2^{\mathrm{ab}}\right) \\
5.9\left(0.2^{\mathrm{b}}\right)\end{array}$ \\
\hline Even-sized & $\begin{array}{l}\text { Conifer } \\
\text { Mixed }\end{array}$ & $\begin{array}{l}21 \\
20\end{array}$ & $\begin{array}{l}4.7\left(0.4^{\mathrm{a}}\right) \\
5.2\left(0.3^{\mathrm{ab}}\right)\end{array}$ \\
\hline \multicolumn{2}{|c|}{$\begin{array}{l}F \text {-value, structure } \\
F \text {-value, tree species } \\
\text { Interaction }\end{array}$} & & $\begin{array}{l}4.16^{*} \\
2.91 \\
0.02\end{array}$ \\
\hline
\end{tabular}

Values with different small letters differ statistically ( $p$ $<0.05$ ) from each other.
The dominant height in even-sized mixed stands differed significantly $(p<0.05)$ from all-sized stands.

\section{DISCUSSION}

The first hypothesis set for this study (ie that mixed (broad leaved-coniferous) stands were better than conifer stands) was confirmed fairly well in all-sized stands. According to Frivold (1982) the yield in mixed stands of birch and spruce in Nonway was better than in pure spruce stands. However, the proportion of birch should be clearly decreased at the age of $40 \mathrm{yr}$ on fertile sites and at the age of $70 \mathrm{yr}$ on barren sites. In Central Europe mixed stands of birch and spruce grew better than pure spruce stands (Otto, 1986).

Previous studies (Phares, 1978) have also shown that species composition plays a role in the yield and development of structurally different stands. The trees in mixed stands are more closely spaced than in conifer stands (Frivold, 1982; Mielikäinen, 1985). Mixed stands also use better the growing space available in the soil in that different tree species, especially spruce and birches, have different rooting depths (Laitakari, 1927, 1934; Sirén, 1955).

The relative growth in stands of diverse structure under corresponding conditions to this study has generally varied within the range of $2-4 \%$ (Barth, 1929; Näslund, 1944; Bøhmer, 1957; Nilsen and Haveraaen, 1983; Lundqvist, 1989). Barth (1929) reported a growth figure $1.7 \mathrm{~m}^{3}$ greater in a Norway spruce-dominated stand of diverse structure than the average for the forest region in question. According to Bøhmer (1957), the growth of Norway spruce in an irregularly uneven-aged stand was equal to the average growth of an even-aged stand.

Indermühle (1978) found the yield in a spruce-dominated all-sized stand in sou- 
thern Germany to be surprisingly high. Ekhart et al(1961) and Mayer (1969) stated in Austria that an all-sized stand grows better than an even-sized one. Smith and DeBald (1978) concluded from several materials in North America that the yield in all-sized forests is slightly higher than that in even-sized ones. Hasse and Ek (1981) have observed all-sized stands in broad leaved forests of North-America to produce more commercial timber than even-sized stands do although their total yield hardly differs. In general, stand structure had little influence on the yield of forest (Burger, 1942; Smith, 1962; Mitscherlich, 1963; Kern, 1966; Gingrich, 1967; Hladik, 1975; Lundqvist, 1989). According to some studies the volume increment in even-sized stands is higher than in all-sized ones (Walker, 1956; Trimble and Manthy, 1966; Trimble and McClung, 1966; McCauley and Trimble, 1972, 1975).

In a simulation-based study, Pukkala and Kolström (1988) estimated the yield of an all-sized (uneven-aged) stand of Norway spruce in southern Finland to be $5 \mathrm{~m}^{3} / \mathrm{ha} / \mathrm{a}$. They compared the simulated growth estimate to the yield tables compiled by Koivisto (1954) for repeatedly treated evensized stands. However, Koivisto's material also included all-sized stands since the majority of forest stands of that time were all-sized in structure (Lähde et al, 1992). Later Kolström (1992) estimated that growth in all-sized stands is about the same as growth in even-sized stands.

When sample plots carrying equivalent average volumes were compared in this study, it was observed that the increment of all-sized mixed stands was greater than that of even-sized conifer stands. The relative growth was greater in all-sized stands than in even-sized stands independently of volume. The difference in dominant height was the inverse. Thus, the hypothesis of even-sized stands possessing greater growth than all-sized stands was not confirmed. The result was quite the opposite.

\section{ACKNOWLEDGMENTS}

We thank M Hagner, JP Schütz, K Andreassen, LH Frivold and 2 anonymous reviewers for manuscript review.

\section{REFERENCES}

Adams DM, Ek AR (1974) Optimizing the management of uneven-aged forest stands. Can J For Res 4, 274-287

Alexander RR, Edminster CB (1978) Regulation and control under uneven-aged management. In: Uneven-aged silviculture management in the United States, US Dep Agric, For Serv Timber management research, Washington, DC Gen Tech Rep WO-24, 217-230

Andreassen K (1992) Volume production and problem with the stability of the stand structure in uneven-aged and multi-layered spruce (Picea abies Karst) forest in Norway. In: Silvicultural alternatives. Proc Internordic Workshop June 22-25 1992 (M Hagner, ed). Swedish University of Agricultural Sciences. Department of Silviculture, Reports, No 35 , 23-28

Baker FS (1934) Theory and Practice of Silviculture. McGraw-Hill Book Company. New York and London, $502 \mathrm{p}$

Barth A (1929) Skjermforyngelsen i produksjons - ökønomisk belysning. Acta For Fenn 34, 1 . 33

Bøhmer JG (1957) Bledningsskog II. Tidsskrift for skogbruk 65, 203-247

Børset O (1963) Skogskjøtsel og skogpleie gjennom 50 ár. Norges landbrukshögskøle, Institutt for skogskjøtsel. $8 \mathrm{p}$

Burger $\mathrm{H}$ (1942) Holz, Blattmenge und Zuwachs. VI. Ein Plenterwald mittlerer Standortsgüte. Der bernische Staatswald Toppwald im Emmental. Mitt Schweiz Anstalt forst Versuchswesen 22, 377-445

Cajander AK (1949) Forest types and their significance. Acta For Fenn 56, 1-71

Cajander EK (1934) Kuusen taimistojen vapauttamisen jälkeisestä pituuskasvusta. Commun Inst For Fenn 19, 1-53

Carbonnier C (1978) Skogarnas vård och föryngring. In: Skogshögskolan 150 år. Sveriges 
Lantbruksuniversitet. Allmänna skrifter nr 2. Uppsala, 85-126

Curtis RO (1978) Growth and yield in unevenaged stands. In: Uneven-aged silviculture and management in the United States, US Dep Agric, For Serv. Timber management research, Washington, DC Gen Tech Rep WO-24, 186-201

Daniel TW, Helms JA, Baker FS (1979) Principles of Silviculture. 2nd ed, McGraw-Hill Book Company. $500 \mathrm{p}$

Doolittle WT (1978) Constraints on forest management in the eastern hardwood region. In: Uneven-aged silviculture and management in the United States, US Dep Agric, For Serv Timber management research, Washington, DC Gen Tech Rep WO-24, 63-66

Ekhart G, Frauendorfer R, Nather J (1961) Die Wälder der Gemeinde Julbach, unter besonderer Bernücksichtigung der stufig aufgebauten Mischwälder. Mitt Forstl Bundes-Vers Anst Mariabrunn 58, 1-93

Eyre FH, Zillgitt WM (1953) Partial cuttings in northern hardwoods of the Lake States. US Dep Agric, Tech Bull 1076, 124 p

Frank RM, Björkbom JC (1973) A Silvicultural Guide for Spruce-Fir in the Northeast. US Dep Agric, For Serv Gen Tech Rep NE6, $23 p$

Frivold LH (1982) Bestandsstruktur og produksjon i blandingskog av bjørk (Betula verrucosa Ehrh, B pubescens Ehrh) og gran (Picea abies (L) Karst) i Sydøst-Norge. Summary: Stand structure and yield of mixed stands of birch (Betula verrucosa Ehrh, B pubescens Ehrh) and spruce (Picea abies (L) Karst) in South East Norway. Meld Nor Landbrukshøgsk 61, $18,108 p$

Gibbs CB (1978) Uneven-aged silviculture and management? Even-aged silviculture and management? Definitions and differences. $I n$ : Uneven-aged silviculture and management in the United States. US Dep Agric, For Serv Timber management research. Washington, DC Gen Tech Rep WO-24, 18-24

Gingrich SF (1967) Measuring and evaluating stocking and stand density in upland hardwood forests in the Central States. For Sci 13, 38-53

Gingrich SF (1978) Growth and yield. In: Uneven-aged silviculture and management in the United States. US Dep Agric, For Serv. Timber management research. Washington, DC Gen Tech Rep WO-24, 115-124
Gould EM (1975) Aesthetics and land use. Proc Logging Residue Conf, Morgantown West Virg. June 4-6, 1975

Hagner M (1992a) Basic ideas behind the new trends in Swedish forestry. In: Silvicultural alternatives. Proc Internordic Workshop June 22-25 1992 (M Hagner, ed). Swedish University of Agricultural Sciences, Department of Silviculture, Reports No 35, 10-12

Hagner M (1992b) Biologiskt och ekonomiskt resultat i fälttörsök med plockhuggning kombinerad med plantering. Abstract: Biological and economical results from experiments with selective felling combined with enrichment planting. The Swedish University of Agricultural Sciences. Department of Silviculture. Working paper $63,1-52$

Haight RG, Getz WM (1987) Fixed and equilibrium endpoint problems in uneven-aged stand management. For Sci 33, 908-931

Hann DW, Bare BB (1979) Uneven-aged forest management: State of the art (or science?) US Dep Agric, For Serv Gen Tech Res INT$50,18 \mathrm{p}$

Hart AC (1964) The Penobscot managementintensity demonstration plots. US Dep Agric, For Serv Res Pas NE-25, $24 p$

Hasse WD, Ek AR (1981) A simulated comparison of yield for even- versus uneven-aged management of northern hardwood stands. $J$ Env Manag 12, 236-246

Hassenkamp W (1955) Das Scheitern der Plenterwirtschaft in Skandinavien. Forstarchiv 26, 241-251

Hatcher RJ (1967) Balsam fir advance growth after cutting in Quebec. For Chron 40, 86-92

Haveraaren O (1992) The background of the new trend in silviculture in Norway. In: Silvicultural alternatives. Proc Internordic Workshop June 22-25 1992 (M Hagner, ed). Swedish University of Agricultural Sciences. Department of Silviculture. Reports, No 35, 13-14

Hawley RC (1946) The Practice of Silviculture. 5th Ed. John Wiley and Sons, Inc New York, $354 \mathrm{p}$

Heinselman ML (1981) Fire and succession in the conifer forests of northern North America. In: Forest succession: Concepts and application (DC West, HH Shugart, DB Botkin, eds). Springer-Verlag New York, 374-405

Hladik M (1975) Die Holzproduktion im gemischten Tannen- und Buchenwald bei einer Kahl- 
schlag- und Plenterwirtschaft. Lesnickej fakulty VSLD vo Zvolene, Zbornik vedeckych Prac 7-2, 55-72

Ilvessalo Y (1920a) Tutkimuksia metsätyyppien taksatoorisesta merkityksestä nojautuen etupäässä kotimaiseen kasvutaulujen laatimistyöhön. Referat: Untersuchungen über die taxatorische Bedeutung der Waldtypen, hauptsächlich auf den Arbeiten für die Aufstellung der neuen Ertragstafeln Finnlands fussend. Acta For Fenn 15, 1-157

Ilvessalo $Y$ (1920b) Kasvu- ja tuottotaulukot Suomen eteläpuoliskon mänty-, kuusi- ja koivumetsille. Referat: Ertragstafeln für die Kiefern, Fichten- und Birkenbestände in der Südhälfte von Finland. Acta For Fenn 15, 1-94

IIvessalo $Y$ (1951) III valtakunnan metsien arviointi. Suunnitelma ja maastotyön ohjeet. Summary: Third national forest survey of Finland. Plan and instructions for field work. Commun Inst For Fenn 39, 1-67

IIvessalo $Y$ (1956) Suomen metsät vuosista 1921-24 vuosiin 1951-53. Kameen valtakunnan metsien inventointiin perustuva tutkimus. Summary: The forests of Finland from 1921-1924 to 1951-1953. A survey based on three national forest inventories. Commun Inst For Fenn 47, 1-227

Indermühle MP (1978) Struktur-, Alters-, und Zuwachsuntersuchungen in einem FichtenPlenterwald des subalpinen Stufe. Beiheft zu den Zeitschriften des Schweizerischen Forstvereins $60,98 p$

Kammerlander $H$ (1978) Autbau, Verjüngung und Verbissgefährdung der Plenterwälder im Raum Kufstein/Tirol. Schweiz Zeit Forstwesen 129, 711-726

Kern KG (1966) Wachstum und Umweltfaktoren im Schlag- und Plenternwald. Vergleichende ertragskundlich-ökologische Untersuchungen in zwei Ta-Fi-(Bu)-Plenternwaldbeständen und zwei benachbarten Fi-Schlagwäldern des Hochschwarzwaldes. Bayerischer Landwirtschaftsverlag, München Basel Wien, 232 p

Klensmeden U (1984) Stamvis blädning. Nágra studier på två försöksytor i Dalarna. Examensarbete 1984-1986. Sveriges lantburksuniversitet. Institutionen för skogsskötsel. Umeá, $38 \mathrm{p}$

Koivisto P (1954) Kasvu- ja tuotostaulukoita. Summary: Growth and yield tables. Commun inst For Fenn 5, 1-49
Kolström T (1992) Dynamics of uneven-aged stands of Norway spruce: A model approach. Metsäntutkimuslaitoksen tiedonantoja 411. The Finnish Forest Research Institute, Research Papers 411, $29 p+$ appendixes

Lähde $E$ (1992) The background ideas to the new trends in silviculture. In: Silvicultural alternatives. Proc Internordic Workshop June 22-25 1992 (M Hagner, ed). Swedish University of Agricultural Sciences. Department of Silviculture Reports, No 35, 17-19

Lähde E, Laiho O, Norokorpi Y, Saksa T (1991) The structure of advanced virgin forest in Finland. Scand J For Res 6 (4), 527-537

Lähde E, Laiho O, Norokorpi Y, Saksa T (1992) Stand structure of thinning and mature conifer-dominated forests in boreal zone. In: Silvicultural alternatives. Proc Internordic Workshop June 22-25 1992 (M Hagner, ed) Swedish University of Agricultural Sciences. Department of Silviculture, Reports, No 35, 58-65

Lähde E, Norokorpi Y, Oikarinen M (1985) Mikkelin ekoläänin metsien vaihtoehtoiset käsittelymallit. Metsäntutkimuslaitoksen tiedonantoja 180. The Finnish Forest Research Institute. Research Papers 180, $67 \mathrm{p}$

Laitakari E (1927) Männyn juuristo. Morfologinen tutkimus. Summary: The root system of pine (Pinus silvestris). A morphological investigation. Acta For Fenn 33 (1), 1-380

Laitakari E (1934) Koivun juuristo. Summary: The root system of birch (Betula verrucosa and odorata). Acta For Fenn 41(2), 1-216

Larsen JA (1980) The boreal ecosystem. Academic Press, New York, $500 p$

Larsen JB (1992) New trends and on-going research in alternative silvicultural methods in Denmark. In: Silvicultural alternatives. Proc Internordic Workshop June 22-25 1992 (M Hagner, ed). Swedish University of Agriculture Sciences. Department of Silviculture, Reports, No 35, 15-16

Leak WB, Graber RE (1976) Seedling input, death, and growth in uneven-aged northern hardwoods. Can J For Res 6 (3), 368-374

Leak WB, Solomon DS, Filip SM (1969) A silvicultural guide for northern hardwoods in the Northeast. US Dep Agric, For Serv Res Pap $\mathrm{NE}-143,34 \mathrm{p}$

Leemans $R$ (1991) Canopy gaps and establishment patterns of spruce (Picea abies (L) Karst) 
in two old-growth coniferous forests in central Sweden. Vegetatio 93, 157-165

de Liocourt $F$ (1898) De l'aménagement des sapinières. Bull Soc For Franche-Comté Belfort 6, 396-405

Lundqvist $L$ (1984) Blädning och etappvis slutawverkning - literaturstudie. Sver Skogsvárdsförb Tidskr 6, 27-40

Lundqvist L (1989) Blädning i granskog. Strukturförändringen, volymtillväxt, inväxning och föryngring pá försöksytor skötta med stamvis blädning. Summary: Use of the selection system in Norway spruce forests - changes in the stand structure, volume increment, ingrowth and regeneration on experimental plots managed with single-tree selection. Dissertation. Sveriges landbruksuniversitat. Institutionen för skogsskötsel. Umeå, $99 \mathrm{p}$

Marquis DA, Solomon DS, Björkbom JC (1969) A silvicultural guide for paper birch in the Northeast. US Dep Agric, For Serv Res Pap NE$130,47 p$

Mayer $\mathrm{H}$ (1969) Long term rationalization of forest enterprises by way of silviculture. Allg Forstzeitschr 23, 40-45

McCauley OD, Trimble GR Jr (1972) Forestry returns evaluated for uneven-aged management in two Appalachian woodlots. USDA For Sen Res Pap NE-244, $12 p+$ illus

McCauley OD, Trimble GR Jr (1975) Site quality in Appalachian hardwoods: the biological and economic response under selection silviculture. USDA For Serv Res Pap NE-312, 22 p + illus

Meyer HA (1952) Structure, growth and drain in balanced uneven-aged forests. J For 50, 85-92

Mielikäinen K (1985) Koivusekoituksen vaikutus kuusikon rakenteeseen ja kehitykseen. Summary: Effect of an admixture of birch on the structure and development of Norway spruce stands. Commun Inst For Fenn 133, $79 \mathrm{p}$

Mikola P (1984) Harsintametsätalous. Summary: Selection system. Silva Fennica 18, 293-301

Mitscherlich $G$ (1963) Untersuchungen in Schlagund Plenterwäldern. Allg Forst Jagdz 134 (1), 1-12

Mustian AP (1978) History and philosophy of silviculture management systems in use today. In: Uneven-aged silviculture and management in the United States. US Dep Agric, For Serv Timber Management Research Gen Tech Rep WO-24, 1-17
Näslund M (1944) Den gamla norrländska granskogens reaktionsförmága efter genomhuggning. Referat: Die Reaktionsfähigkeit des alten norrländischen Fichtenwaldes nach Durchauung. Medd Statens skogsförsöksanstalt 33, 1-194

Nilsen P, Haveraaen O (1983) Årringbredder hos gjenstående traer etter hogst i eldre granskog. Rapport fra Norsk Institutt for skogforskning 9/83, 1-16

Norokorpi $Y$ (1992) Natural structure and development of forests as a basis for alternative silvicultural methods in northern Finland. In: Silvicultural alternatives. Proc Internordic Workshop June 22-25 1992 (M Hagner, ed). Swedish University of Agricultural Sciences. Department of Silviculture. Reports No 35, 78-85

Oliver CD, Larson BC (1990) Forest stand dynamics. McGraw-Hill, New York, $467 p$

Otto HJ (1986) Standörtliche Voraussetzungen, Ziele und Waldbautechnik in Fichten-BuchenMischbeständen des Harges. Allg Forst Jagdztg 157, 10, 199-196, 11, 214-222

Phares RE (1978) Research gaps and research needs for the eastern forest regions. In: Uneven-aged silviculture and management in the United States. US Dep Agric, For Serv Timber Management Research. Washington, DC Gen Tech Rep WO-24, 152-157

Pobedinski AV (1988) Comparative evaluation of even-aged and uneven-aged stands (in Russia). Lesnoe Khozyaistvo 2, 40-43

Pretzsch H (1985) Die Fichten-Tannen-BuchenPlenterwaldversuche in den ostbayerischen Forstämtern Freyung und Bodenmais. Forstarchiv 56, 3-9

Pukkala T, Kolström T (1988) Simulation of the development of Norway spruce stands using a transition matrix. For Ecol Manage 25, 255267

Sarvas $R$ (1944) Tukkipuun harsintojen vaikutus Etelä-Suomen yksityismetsiin. Referat: Einwirkung der Sägestammplenterungen auf die Privatwâlder Südfinnlands. Commun Inst For Fenn 33, 1-268

Schütz JP (1969) Étude des phénomènes de la croissance en hauteur et en diamètre du sapin (Abies alba Mill) et de l'épicéa (Picea abies Karst) dans deux peuplements jardinés et une forêt vierge. Supplément aux organes de la Société forestière suisses, $44,1-114$ 
Sirén $G$ (1955) The development of spruce forest on raw humus sites in northern Finland and its ecology. Acta For Fenn 62 (4), 1-408

Smith DM (1962) The practice of silviculture. John Wiley and Sons. New York, $578 p$

Smith DM (1972) The continuing evolution of silvicultural practice. J For 70 (2), 89-92

Smith DM (1975) Dangers in over-simplification of forestry. Maine For Rev 8, 3-4

Smith HC, DeBald PS (1978) Economics of evenaged and uneven-aged silviculture and management in eastern hardwoods. In: Unevenaged silviculture and management in the United States. US Dep Agric, For Serv Timber management research. Washington, DC Gen Tech Rep WO-24, 125-141

Solomon DS, Hosmer RA, Hayslett HT Jr (1986) A two-stage matrix model for predicting growth of forest stands in the northeast. Can J For Res 16 (3), 521-528

Szwagrzyk J (1992) Small scale spatial patterns of trees in a mixed Pinus sylvestris - Fagus sylvatica forest. For Ecol Manage 51, 301 315

Trimble Gr Jr (1961) Managing mountain hardwoods - a ten-year appraisal. US Dep Agric, For Serv NEFES Pap 143, 25 p

Trimble GR Jr (1968) Research findings on evenaged management in hardwoods in the Appalachian area of the Central States. Monongahela NF Timber Management Conf Proc, $15 p$
Trimble GR Jr (1970) 20 years of intensive uneven-aged management. Effect on growth, yield, and species composition in two hardwood stands in West Virginia. US Dep Agric, For Sen Res Pap NE-154, $12 p$

Trimble GR Jr, Manthy RS (1966) Implications of even-aged management on timber. In: Trends from selection cutting to even-aged management. Soc Am For, Allegheny Sect Proc 1965, 62-75

Trimble GR Jr, McClung $L$ (1966) Clearcutting profitable. WV Conserv 30, 2-4

Uppskattning av Sveriges skogstillgångar verkställd åren 1923-1929 (1932) Redogörelse avgiven av riksskogstaxeringsnämnden. Del I. Statens Offentliga Utredningar 26, 1 254

Viitala R (1986) Skandinavian eri-ikäisrakenteisista metsistä. In: Erirakenteisen metsän hoidosta (R Viitala, ed). Metsäntutkimuslaitoksen tiedonantoja 219. The Finnish Forest Research Institute. Department of Silviculture. Research Papers 219, 49-77

Vrablec JJ (1977) Public lands - from concept to practice. US Dep Agric, For Serv Gen Tech Rep NE-29, 77-81

Vuokila $Y$ (1970) Harsintaperiaate kasvatushakkuissa. Summary: Selection from above in intermediate cuttings. Acta For Fenn 110, 1-45

Walker N (1956) Growing stock volumes in unmanaged and managed forests. J For 54, 378383 